Ин-т систем энергетики им. Л.А. Мелентьева. - Новосибирск: Изд-во СО РАН, 2011. $198 \mathrm{c}$.

3. Надежность топливо- и энергоснабжения и живучесть систем энергетики регионов России / Под науч. ред. Н.И. Воропая, А.И. Татаркина; Л.Л. Богатырев [и др.]; - Екатеринбург: Изд-во Урал.ун-та, 2003. - 392 с.

4. Надежность систем энергетики: Проблемы, модели и методы их решения / А.Ф. Дьяков, В.А. Стенников, С.М. Сендеров и др.; отв.ред. Н.И. Воропай. Новосибирск: Наука, 2014. - 284 с.

5. Захаров. В.Е. Подход к оценке приоритетов инвестиционных проектов при управлении развитием децентрализованных зон энергетической системы региона Севера / Промышленная энергетика. 2016. №4 с. 9-13.

6. Захаров В.Е., Прохоров Д.В., Гаврилов В.Л. Потери энергетической ценности рядового угля при доставке до арктических потребителей Республики Саха (Якутия) / Известия высших учебных заведений. Проблемы энергетики. 2013. №5-6. С. $13-22$.

\title{
Энергоэффективная усадьба в Арктической зоне России
}

\author{
Владимиров М.М., магистрант, \\ Ноговицын И.Д., магистрант, \\ Парников А.М., магистрант, \\ Северо-Восточный федеральный университет, \\ 2. Якутск \\ E-mail: inogovitcyn@gmail.com
}

Научный руководитель: к.т.н., доцент Иванова А.В.

В настоящее время разрабатывается множество проектов и технических решений для строительства энергоффективных домов. Однако вместе со строительством новых домов необходимо модернизировать и оптимизировать существующие, для достижения наиболее глобального эффекта по снижению потребления энергетических ресурсов страной [1]. Так же стоит учитывать, что здания и сооружения, расположенные на Крайнем Севере, или территориях приравненных к ним, обладают наибольшим потенциалом энергосбережения. Но, к сожалению, оптимизация энергопотребления зданий и сооружений в данных условиях на данный момент мало изучена.

В связи с вышесказанным, нами поставлена цель: разработать проект энергоэффективной усадьбы в Арктической зоне России.

Для достижения данной цели поставлены следующие задачи:

1. Разработать проект энергоэффективной усадьбы в Арктической зоне России;

2. Подобрать наиболее оптимальный и экономически обоснованный солнечный коллектор и определить период его эффективной эксплуатации в течение года для отопления ИЖД в заданных условиях;

3. Произвести расчет необходимых размеров теплового насоса «земля-вода» и рассчитать эффективность его использования для отопления ИЖД в заданных условиях; 
Результаты произведенных расчетов могут быть использованы при проведении оптимизации энергопотребления существующих зданий и сооружений. Данные мероприятия могут внедряться в рамках энергосервисных контрактов государственным и муниципальным предприятиям. Таким образом, целевая аудитория данного проекта обширна: от частных лиц, желающих оптимизировать свой дом, до государства в целом, для ускорения достижения поставленной цели - сокращение энергоемкости отечественной экономики на 40\%.

В данном проекте рассматривается 2-х этажный ИЖД, расположенный в г. Якутск, Республика Саха (Якутия). Расчетные параметры наружного воздуха приняты по таблице 3.1 СП 131.13330.2012 «Строительная климатология».

Для определения необходимой тепловой нагрузки в соответствии с СП 50.13330.2012 «Тепловая защита зданий» произведен расчет тепловых потерь данного дома. Для расчетного периода данное значение составило $\mathrm{Q}=18,09$ кВт.

Подбор солнечного коллектора и определение период его эффективной эксплуатации в течение года для отопления ИЖД в заданных условиях

Для расчета периода эффективной эксплуатации солнечного коллектора, необходимо определить значение суммарной солнечной радиации. Данные значения принимаем по таблице 8.1 СП 131.13330.2012 «Строительная климатология». Занесем значения в таблицу 1.

Таблица 1

Значение суммарной солнечной радиации, кВт*ч/м2

\begin{tabular}{|l|l|l|l|l|l|l|l|}
\hline Месяц & $\begin{array}{l}\text { Солн. } \\
\text { рад }\end{array}$ & Месяц & $\begin{array}{l}\text { Солн. } \\
\text { рад }\end{array}$ & Месяц & $\begin{array}{l}\text { Солн. } \\
\text { рад }\end{array}$ & Месяц & $\begin{array}{l}\text { Солн. } \\
\text { рад }\end{array}$ \\
\hline Январь & 14,5 & Апрель & 166,5 & Июль & 238 & Октябрь & 53 \\
\hline Февраль & 42 & Май & 229,5 & Август & 180,5 & Ноябрь & 39 \\
\hline Март & 113 & Июнь & 242 & Сентябрь & 118,5 & Декабрь & 13 \\
\hline
\end{tabular}

Подберем наиболее подходящий солнечный коллектор. Рассмотрим 7 вариантов. Во всех коллекторах используются одинаковые трубки типа «U». Длина трубки 2,1 м., диаметр 0,058 м. КПД примем 80\%.

Тепловая мощность коллектора представляет собой произведение суммарной солнечной радиации данного месяца, поглощающей площади коллектора и КПД. Определим тепловую мощность каждого из коллекторов по месяцам. Результаты занесем в таблицу 2.

Таблица 2

Тепловая мощность коллекторов

\begin{tabular}{|c|c|c|c|c|c|c|c|}
\hline \multirow{2}{*}{ Месяц } & \multicolumn{7}{|c|}{ Номер коллектора/ Тепловая мощность, Вж*ч } \\
\cline { 2 - 8 } & 1 & 2 & 3 & 4 & 5 & 6 & 7 \\
\hline Январь & 28,25 & 84,77 & 113,03 & 169,54 & 226,06 & 339,09 & 847,72 \\
\hline Февраль & 81,84 & 245,54 & 327,39 & 491,09 & 654,79 & 982,19 & 2455,48 \\
\hline Март & 220,21 & 660,64 & 880,85 & 1321,28 & 1761,71 & 2642,57 & 6606,43 \\
\hline Апрель & 324,47 & 973,42 & 1297,9 & 1946,85 & 2595,8 & 3893,7 & 9734,25 \\
\hline Май & 447,24 & 1341,74 & 1788,99 & 2683,49 & 3577,99 & 5366,99 & 13417,48 \\
\hline Сентябрь & 230,93 & 692,79 & 923,73 & 1385,59 & 1847,46 & 2771,19 & 6927,98 \\
\hline Октябрь & 103,28 & 309,85 & 413,14 & 619,71 & 826,29 & 1239,43 & 3098,59 \\
\hline Ноябрь & 76 & 228 & 304,01 & 456,01 & 608,02 & 912,03 & 2280,09 \\
\hline Декабрь & 25,33 & 76 & 101,33 & 152 & 202,67 & 304,01 & 760,03 \\
\hline
\end{tabular}


Для наиболее наглядного получения представления о зависимости тепловой мощности каждого из коллекторов от месяца года, представим результаты в виде графика. На оси абсцисс представлены месяцы года, на оси ординат - тепловая мощность, Вт.

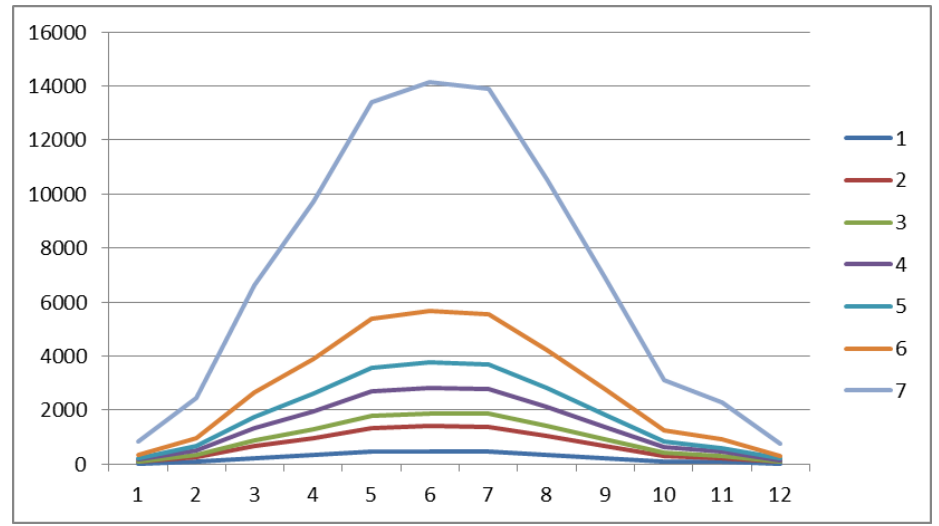

Рис. 1. График зависимости тепловой мощности коллектора от времени года

Проанализировав полученные данные, можно выделить 2 наиболее подходящих солнечных коллектора: коллектор №2 и коллектор №3. Первый в мае покрывает потребность в тепловой энергии на 98,4\%, в сентябре - на 39,4\%. Второй из перечисленных в мае - на $131,2 \%$, в сентябре - на 52,5\%. Остальные не рассматриваются, так как с учетом их стоимости экономически не обоснованы. Возможно, использование коллектора №2 вместе с тепловым насосом будет более обосновано. Поэтому, рассмотрим использование теплового насоса.

Подбор теплового насоса «земля-вода» и определение периода его эффективной эксплуатации в течение года для отопления ИЖД

Подберем наиболее подходящий тепловой насос. Тепловой насос типа «землявода» с рабочей жидкостью «рассол». Марка теплового насоса BWS-1. Рассмотрим 5 различных вариантов исполнения теплового насоса.

Учитывая практически постоянную температуру грунта, данные значения справедливы для всего года. Предполагается, что выбранный тепловой насос будет использован вкупе с солнечным коллектором для отопления ИЖД в период с апреля по октябрь, а также для подогрева воды системы горячего водоснабжения дома (ГВС). Наибольшая недостача мощности среди этих месяцев наблюдается в октябре, и составляет 5,386 кВт. В случае, если подбираемый тепловой насос сможет обеспечить данное количество тепловой энергии, то можно будет сделать вывод, что он обеспечит недостающую солнечному коллектору мощность для 100\%-ого покрытия потребности системы отопления в период с апреля по октябрь.

Необходимая максимальная тепловая мощность теплового насоса рассчитывается по следующей формуле:

$$
Q_{W P}=\left(Q_{G}+Q_{W W}\right) \times Z
$$

где $\mathrm{Q}_{\mathrm{wP}}$ - необходимая макс. мощность теплового насоса;

$\mathrm{Q}_{\mathrm{G}}-$ отопительная нагрузка здания. Принимаем равным 5,386 кВт;

$\mathrm{Q}_{\mathrm{Ww}}$ - потребляемая мощность для водоподготовки. Принимаем равным 1 кВТ $(0,25$ кВт/чел*4(человек в семье))

$\mathrm{Z}$ - фактор блокировки времени. Принимаем равным 1,1 . 
Подставив вышеуказанные значения в формулу (1), вычислили максимальную тепловую мощность теплового насоса $\mathrm{Q}_{\mathrm{wP}}=7.025$ кВт.

Наиболее подходящим тепловым насосом является BWS-1-8, с мощностью охлаждения 6,6 кВт. В таком случае для нужд системы отопления остается 5,6 кВт энергии.

Рассчитаем, количество тепловой энергии, вырабатываемой солнечным коллектором и тепловым насосом вместе, и сравним с необходимым количеством тепловой энергии для нужд системы отопления по месяцам. Результаты сравнения представлены в таблице 3.

Таблица 3

Тепловой баланс

\begin{tabular}{|l|l|l|l|l|l|}
\hline Месяц & $\begin{array}{c}\text { Необх. кол-во } \\
\text { тепл. энергии } \\
\text { для системы } \\
\text { отопления, Вт }\end{array}$ & $\begin{array}{c}\text { Кол-во } \\
\text { тепловой } \\
\text { энергии солн. } \\
\text { коллектора, } \\
\text { Вт }\end{array}$ & $\begin{array}{c}\text { Кол-во } \\
\text { тепловой } \\
\text { энергии } \\
\text { тепл. } \\
\text { насоса, Вт }\end{array}$ & $\begin{array}{c}\text { Суммарное } \\
\text { кол-во } \\
\text { тепловой } \\
\text { энергии, Вт }\end{array}$ & $\begin{array}{c}\text { \% от } \\
\text { необходимого } \\
\text { кол-ва } \\
\text { энергии, \% }\end{array}$ \\
\hline январь & 14643,01 & 84,77 & 5600 & 5684,77 & 38,82241424 \\
\hline февраль & 13340,58 & 245,54 & 5600 & 5845,54 & 43,81773506 \\
\hline март & 9320,01 & 660,64 & 5600 & 6260,64 & 67,17417685 \\
\hline апрель & 4903,05 & 973,42 & 5600 & 6573,42 & 134,0679781 \\
\hline май & 1363,82 & 1341,74 & 5600 & 6941,74 & 508,992389 \\
\hline июнь & $-1127,8$ & 1414,82 & 5600 & 7014,82 & $-621,9914879$ \\
\hline июль & $-1977,21$ & 1391,44 & 5600 & 6991,44 & $-353,6012867$ \\
\hline август & $-844,66$ & 1055,27 & 5600 & 6655,27 & $-787,9229512$ \\
\hline сентябрь & 1760,22 & 692,79 & 5600 & 6292,79 & 357,5001988 \\
\hline октябрь & 5695,84 & 309,85 & 5600 & 5909,85 & 103,7573036 \\
\hline ноябрь & 11415,24 & 228 & 5600 & 5828 & 51,05455514 \\
\hline декабрь & 14218,31 & 76 & 5600 & 5676 & 39,92035622 \\
\hline
\end{tabular}

В таблице 3 зеленым цветом выделены месяцы, в которых потребность системы отопления в тепловой энергии покрыта на 100\%. Желтым - потребность покрыта от 50\% до 99\%. Красным - покрыто менее 49\% потребности ИЖД в тепловой энергии. Июнь, июль, август - не отопительные месяцы (выделены серым цветом).

Проанализировав полученные данные, можно установить, что в период с декабря по февраль использование альтернативных источников энергии не оправдано. В месяцы март, апрель и ноябрь ввиду относительно небольшой эффективности солнечного коллектора, и достаточной мощности теплового насоса, в использовании солнечного коллектора нет необходимости. При этом в марте и ноябре тепловой насос работает в бивалентном альтернативном режиме, т.е. второй теплогенератор (газовый котел) включается, если тепловой насос не справляется. В период с мая по август тепловой насос не используется.

По результатам выполненной работы можно сделать вывод, что использование альтернативных источников тепловой энергии является оправданным. Повсеместное внедрение вышеописанных энергосберегающих мероприятий позволит в первую очередь снизить потребление энергетических ресурсов Россией. Помимо этого, пользователи, установившие в своем доме такие системы, смогут значительно сэкономить на оплате коммунальных расходов, что окажет положительное влияние на 
повышение уровня и качества жизни граждан Российской Федерации, и улучшение имиджа страны как идущей в ногу со временем. Помимо всего вышесказанного, уменьшение потребления природного газа означает снижение выбросов диоксида азота, оксида углерода, бензапирена и иных веществ, выделяющихся при сжигании природного газа. Данный факт окажет положительное влияние на экологию Земли.

Список литературы:

1. Генцлер И.В., Петрова Е.Ф. Сиваев С.Б. Энергосбережение в многоквартирном доме. - Тверь: Научная книга, 2009. - 130 с. - ISBN 978-5-904380-08-9.

2. Свод правил 50.13330.2012 Тепловая защита зданий. - М.: Министерство регионального развития Российской Федерации, 2012.

3. Свод правил 131.13330.2012 Строительная климатология. - М.: Министерство регионального развития Российской Федерации, 2012.

\title{
Емкостной отбор мощности от высоковольтных линий электропередачи
}

\author{
Рожина М.А., аспирант, \\ Северо-Восточный федеральный университет, \\ 2. Якутск \\ E-mail:djmik_90@bk.ru
}

Научный руководитель: о.m.н., профессор Бурянина Н.С.

Проблемы энергетики республики Саха (Якутии) обусловлены ее территорией и не заселенностью. Располагая шестой частью территории России, Республика имеет всего около миллиона населения. Якутия разделяется на 4 энергорайона - это Центральный энергорайона, Западный энергорайон, Южно-Якутский энергорайон и Северный энергорайон. В этих четырех энергорайонах проживает более 900 тысяч человек.

Северный энергорайон, который занимает $2 / 3$ территории всей республики $(2,2$ млн. км²). Общая установленная мощность - 184,9 МВт (электроэнергия) и 92,4 Гкал/ч (теплоэнергия). Основными источниками являются дизельные электростанции, но, кроме этого есть 8 солнечных электростанций и 2 ветроэнергетических установки. Изза большого количества ДЭС остро стоит проблема завоза топлива, и соответственно высока себестоимость электроэнергии.

Bce энергорайоны $\kappa$ настоящему времени не связаны между собой электрическими сетями. Сейчас ведется строительство крупных межсистемных ЛЭП: ВЛ-220 кВ «Чернышевский-Мирный-Ленск-Пеледуй» и ВЛ-220 кВ «Нижний Куранах-Томмот-Майя», которые позволят соединить разрозненные энергорайоны в единую энергосистему.

В перспективе следует учитывать также и связь Якутских электрических сетей с Магаданскими.

В связи с выше изложенным можно сказать, что из-за слабой заселенностью территории Республики. Линии электропередачи 110 - 220 кВ прокладываются вдоль дорог, на которых имеются населенные пункты из нескольких домов, геологические 